\title{
ネオニコチノイドの選択毒性の分子基盤\#
}

\author{
松田一彦*
}

近畿大学農学部農芸化学科

(平成 14 年 8 月 7 日受理)

\section{Molecular Basis of Selective Toxicity of Neonicotinoids}

\author{
Kazuhiko MATSUDA \\ Department of Agricultural Chemistry, Faculty of Agriculture, Kinki University, 3327-204 Nakamachi, Nara \\ 631-8505, Japan
}

Key words: neonicotinoid, imidacloprid, nicotinic acetylcholine receptor, selective toxicity, two-electrode voltage-clamp, Xenopus laevis oocyte.

\section{1. はじめに}

ネオニコチノイドと総称されるイミダクロプリドおよび 関連殺虫剂（困 1) は，殺虫活性，選択毒性および植物中で の浸透移行性に優れ，既存の殺虫剂に対して抵抗性を示す 昆虫に対しても卓効を示すことから，今や世界中で多用さ れている. かつて本殺虫剂群は，芳香環部分の構造に基づ いてクロロニコチニル系殺虫剂とも呼ばれていたが，現在 ではその定義に当てはまらない化合物が数多く見られる (困 1). ネオニコチノイドは, 昆虫のニコチン性アセチルコ リン受容体 (nAChR) に対して選択的にアゴニストとして 作用することにより，殺虫活性を発揮する。このことに興 味を抱いた筆者は，ネオニコチノイドの選択性をもたらす 分子機構についてこれまで研究してきた11. その結果, 昆虫 の nAChRに対するネオニコチノイドの選択性は，化合物 の物理化学的性質と受容体の構造をつき合わせることによ り，論理的に説明することができることがわかった。

\section{2. ネオニコチノイドの構造と選択毒性}

これまでに実用化されたネオニコチノイドは，活性発現 および選択毒性に重要な役割を果たす部分構造として，二 トロイミン，ニトロメチレンあるいはシアノイミン構造の いずれかを持つ.これらの電子求引性官能基に隣接する 3 級窒素原子 (図 1) は電子不足の状態となり, nAChR と相

\footnotetext{
\#第 27 回大会シンポジウムの講演者による解説.

*干631-8505 奈良市中町 3327-204

E-mail : kmatsuda@nara.kindai.ac.jp
}

互作用するときにアセチルコリンの 4 級窒素原子に対応す る役割を果たすと言われている ${ }^{2)}$ ところが, 真空中でイミ ダクロプリドのイミダゾリジン部の電荷を半経験的分子軌 道法により計算すると，イミダクロプリドの 3 級窒素原子 の電荷が極めて小さく見積もられるため，受容体との相互 作用における 3 級窒素原子の役割を疑問視する意見もあ $ろ^{3)}$. 筆者らは，ニトロ基やシアノ基の水素結合と分子全体 の溶媒和を考慮し, 半経験的分子軌道法である AMSOL プ ログラムを用いてイミダクロプリドのイミダゾリジン部の 電荷を計算した。 その結果，ニトロ基をアンモニウムと水 素結合させて計算することにより，イミダクロプリドのイ ミダゾリジン部の窒素原子が正電荷を持つことを見出し た ${ }^{1)}$. しかもその正電荷は，イミダゾリジン環全体に広く分 布し，1 位の窒素原子よりも 3 位の窒素原子にやや偏って いた。これらの結果から，亲ニコチノイドが昆虫の $\mathrm{nAChR}$ と相互作用するとき，ニトロ基やシアノ基が静電 的な力により受容体の塩基性アミノ酸残基に接近し, つい でそれらと水素結合することによりイミダゾリジン部は 2 つの窒素原子を中心にして正電荷を帯び, 受容体に強固に 結合するのではないかと推定された。

\section{3. ニコチン性アセチルコリン受容体の構造と ネオニコチノイド感受性 一へテロ型受容体を用いた解析一}

$\mathrm{nAChR}$ は，2つの $\alpha$ サブュニットと 3 つの non- $\alpha$ サブ ユニットから成る糖蛋白質であり，中央にカチオンを選択 的に通すイオンチャネルを持つ（図 2) ${ }^{1,4-7)}$. しかし, 例外 

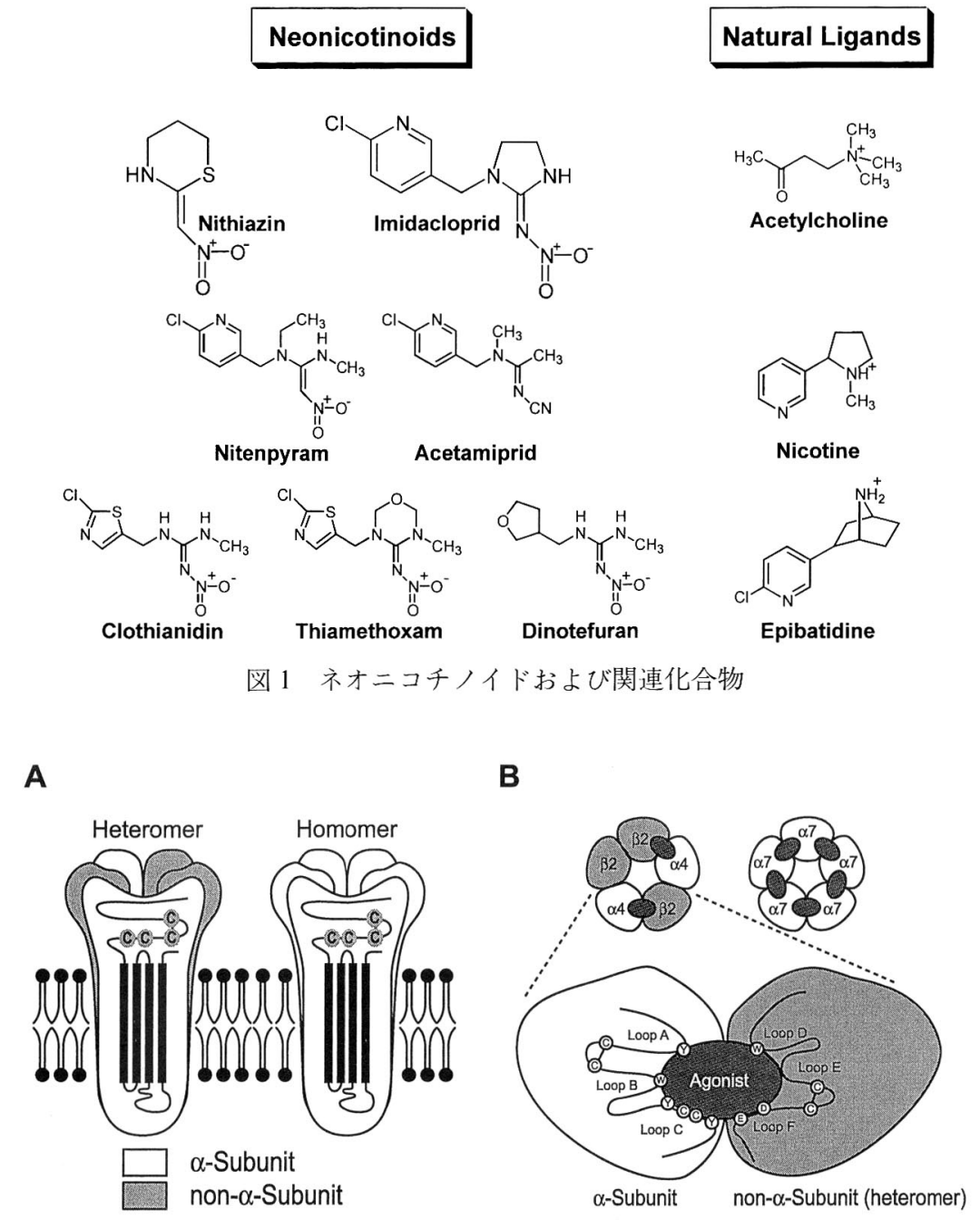

図 2 ニコチン性アセチルコリン受容体の構造の模式図

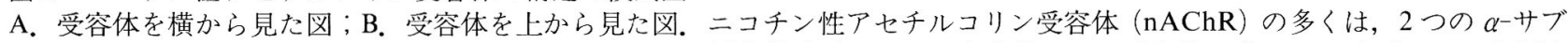

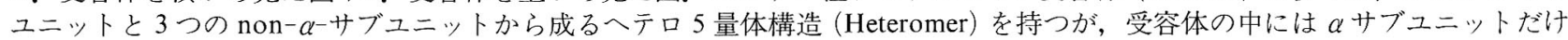
から成る (Homomer) ものもある (A，B)。アゴニストおよびアンタゴニストとの相互作用に関与する“リガンド結合部位”は， loop A loop F と呼ばれ， $\alpha$-サブユニットと non- $\alpha$-サブユニットの境界領域に局在する (B). アゴニストの結合に重要な役割 を果たしていると言われているアミノ酸残基を，アルファベット一文字で表記した．本図は, Elsevier Science の許可を得て, 文 献 1 (版権の発生：2001 年）の図 3 党改変して作成した.

的に $\alpha 7 \sim \alpha 9$ サブユニットは, 単独でホモ 5 量体型 $\mathrm{nAChR}$ をつくる ${ }^{8-10)}$. アセチルコリンが $\alpha$ サブュニットと non- $\alpha$ サブユニットの境界に結合すると, イオンチャネルが開口 する.アセチルコリンとの相互作用に関与する領域は, $\alpha$ サ ブユニット抢よび non- $\alpha$ サブュニットの $\mathrm{N}$ 末端から第一 膜貫通部位までの間に局在し, loop A l loop F と呼ばれて いる ${ }^{1,5,6)}$ ここれらのうち, loop $\mathrm{A} \sim \operatorname{loop} \mathrm{C}$ は $\alpha$ サブュニッ 卜上に, loop D l loop F は non- $\alpha$ サブユニット上に存在す る(図 2).

イミダクロプリドは nAChRに対してアゴニストとして 作用することから,アセチルコリンと結合部位を共有する. よって, $\alpha$ サブュニット拈よび non- $\alpha$ サブユニットは, 程度
の差はあれども，ともに昆虫のnAChRに対するイミダク ロプリドの選択性に寄与寸ると推測された。筆者は, ショ ウジョウバエnAChRの $\alpha$ サブュニットが七ヨコの $\beta 2$ (non- $\alpha$ ) サブュニットとハイブリッド受容体をつくること を利用して ${ }^{11)}$ ，八イブリッド受容体と $\alpha 4 \beta 2$ 受容体のイミ ダクロプリド感受性を電気生理学的手法により比較した。 その結果，ハイブリッド受容体の方が $\alpha 4 \beta 2$ 受容体よりも はるかに高いイミダクロプリド感受性を示すことを見出 し，昆虫の nAChRに対寸るネオニコチノイドの高い親和 性に $\alpha$ サブユニットが染く関与することを明らかにし た $^{12)}$. 


\section{4. ニコチン性アセチルコリン受容体の構造と ネオニコチノイド感受性 一ホモ 5 量体型受容体を用いた解析一}

$\alpha 7$ サブユニットは単独で nAChR をつくることから ${ }^{8)}, \alpha$ サブユニットでありながら loop D loop F を有する.この 中で, loop F はアセチルコリンの 4 級窒素原子と静電的に 相互作用すると言われており，ネガティブサブサイトとも 呼ばれている4).イミダクロプリドのイミダゾリジン部の 窒素原子は，二トロ基が水素結合しない限り中性に近い. 一方，アセチルコリンの窒素原子は常に正電荷を有する。 さらにアセチルコリンは，負電荷を有するニトロ基を持た ない.このような分子中の電荷分布の差は, nAChR の loop $\mathrm{F}$ との相互作用に影響すると予想されたため, loop F に変 異を有する $\alpha 7 \mathrm{nAChR}$ を数種つくり，ネオニコチノイドお よびアセチルコリンをはじめとする天然アゴニストに対す る変異体の応答を, 野生型受容体の応答と比較した ${ }^{13)} . \alpha 7$ $\mathrm{nAChR} の$ loop F に G189D (Gly $\rightarrow$ Asp) あるいは G189E $(\mathrm{Gly} \rightarrow \mathrm{Glu})$ 変異を導入すると, 受容体のネオニコチノイ ド感受性は顕著に低下寸るのに対して，G189N（Gly $\rightarrow$ Asn) あるいは G189Q (Gly $\rightarrow \mathrm{Gln})$ 変異を導入しても受容 体の殺虫剂感受性はほとんど変化しなかった（図 3)。一方 これらの 4 種の変異は，アセチルコリンのみならずイミダ クロプリドの脱ニトロ体に対する受容体の応答にもほとん ど影響をおよぼさなかったことから，G189D拈よび

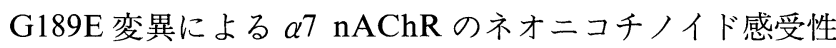
の低下は，負電荷を持つアスパラギン酸残基あるいはグル タミン酸残基とネオニコチノイドの負電荷を持つニトロ基 との静電的な反発によるものと推定された，すなわち，ネ オニコチノイドが nAChRに結合するとき, nAChRの loop F がネオニコチノイドのニトロ基の近傍に位置する ことが示唆された ${ }^{13)}$. しかし，この知見だけでは昆虫の $\mathrm{nAChR}$ に対するネオニコチノイドの選択性を説明するこ

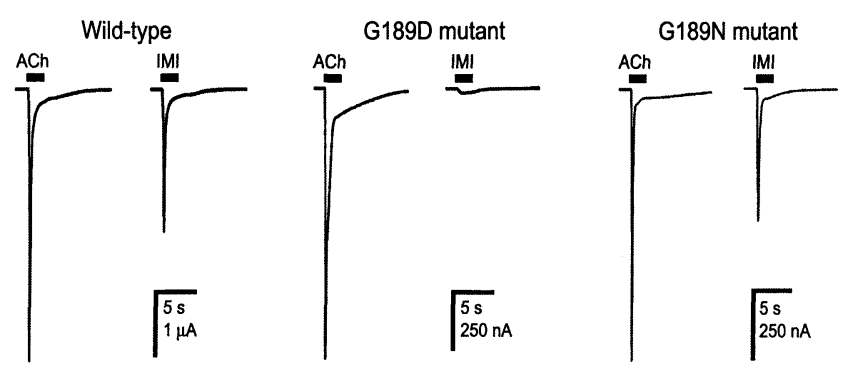

図 3 野生型およびloop F に変異を有する $\alpha 7$ ニコチン性 アセチルコリン受容体のアセチルコリン $(\mathrm{ACh})$ およびイミ ダクロプリド (IMI) に対する最大応答の比較。本図は, Elsevier Science (文献 1 の図 3, 版権の発生：2001 年) およ び Nature Publishing Group (文献 13 の図 2 および図 3, 版 権の発生：2000 年) の許可を得て作成した.
とができなかった.

\section{5. アセチルコリン結合蛋白質の 3 次元構造と ネオニコチノイド結合部位}

上記の問題を解決する方法について考えていたとき，軟 体動物の一種である Lymnaea stagnalis からアセチルコリ ン結合蛋白質 (AChBP) が発見され ${ }^{14)}$ ，その結晶構造も合 わせて解明された ${ }^{15)}$. AChBP は，グリア細胞からコリン作 動性シナプスに放出され，アセチルコリンと結合すること によりシナプスにおけるアセチルコリン濃度の上昇を抑制 する. AChBP は膜貫通構造を持たない水溶性蛋白質であ るが， $\alpha 7 \mathrm{nAChR} の \mathrm{~N}$ 末端から第一膜貫通部位までのアミ ノ酸配列，すなわちアゴニスト結合部位である loop A 〜 loop F を全て保有し， $\alpha 7 \mathrm{nAChR}$ と同様にホモ 5 量体を 形成する ${ }^{14)}$. 筆者は， $\alpha 7 \mathrm{nAChR}$ を実験材料として用いて いたことに幸運を感じながら AChBP の結晶構造を参照し たところ， $\alpha 7 \mathrm{nAChR} の \mathrm{G} 189$ に対応する AChBP のアミ ノ酸残基 Y164 が，アゴニスト結合部位に面していること を見出した。これまで， loop F では 2 種の酸性アミノ酸残 基がアゴニストとの静電的相互作用に関与寸ると言われて いたが4)，それらはカルシウムイオンとの結合に関与する との説もあり（AChBPの結晶構造ではカルシウムイオン と配位結合していた $)^{5}$ ，アゴニストの結合に直接関与する アミノ酸残基は未確定であった。そのアミノ酸残基の位置 を，筆者らは AChBP の結晶構造の解明以前に確定してい たのである.

これまで進めてきた研究が的外れではないことに意を強 くして，AChBPの結晶構造をさらに詳しく調べた。 $\alpha 7$ nAChRの G189 がイミダクロプリドのニトロ基の近傍に 位置することが正しいとすると, AChBP のY164 近傍に存 在するアミノ酸残基に対応する $\alpha 7 \mathrm{nAChR}$ 上のアミノ酸 残基も，イミダクロプリドのニトロ基との相互作用に関与 するかもしれない.そこまで考えたとき，AChBPの結晶構 においてY164の近傍に存在するアミノ酸残基 Gln55 に目 が止まった。このアミノ酸残基に対応する $\alpha 7 \mathrm{nAChR} の ア$ ミノ酸残基もグルタミン残基 $(\mathrm{G} \ln 79)$ であり， loop D に 位置する。これを酸性アミノ酸あるいは塩基性アミノ酸残 基に置換すると， $\alpha 7 \mathrm{nAChR} の$ ネニコチノイド感受性は 激変すると予想された。果たして，この予想は正しかっ $た^{16)}$.

$\alpha 7 \mathrm{nAChR}$ の Gln79 をグルタミン酸残基に置換すると (Q79E 変異), 受容体のネオニコチノイド感受性は顕著に 抑制された。これは，グルタミン酸残基のカルボキシレー トとネオニコチノイドのニトロ基が静電的に反発したため と考えると説明することができる。一方，グルタミン残基 をリジン残基（Q79K）あるいはアルギニン残基（Q79R） に置換すると，受容体のネオニコチノイド感受性は有意に 
増大した。 これは, 正電荷を持つ塭基性残基とネオニコチ ノイドのニトロ基が静電的に引きあったためと考えると矛 盾が無い.さらに Q79K および Q79Rによる $\alpha 7 \mathrm{nAChR} の$ ネオニコチノイド感受性の増大には, 塩基性残基とネオニ コチノイドのニトロ基間における水素結合の形成も関与し ている可能性があると考えられた ${ }^{16)}$.いずれにせよ， $\alpha 7$ $\mathrm{nAChR}$ のネオニコチノイドの感受性が $\mathrm{N}$ 末端に近い loop D に存在する $\mathrm{G} \ln 79$ の塩基性アミノ酸残基の変化に より顕著に増大することは，実験事実として間違いない。 このことをふまえて，これまでに昆虫から見出された nAChR の non- $\alpha$ サブュニットについて， $\alpha 7$ nAChRの Gln79 に対応するアミノ酸残基を調べたところ, 大部分の サブユニットが塩基性アミノ酸残基を持つことを見出し た.これらのアミノ酸残基は, 昆虫の $\mathrm{nAChR}$ に対するネオ ニコチノイドの強い作用に関与するアミノ酸残基のUとつ であり, 他のアミノ酸残基に変異すると, 受容体のネオ二 コチノイド感受性が顕著に低下すると予測された ${ }^{16)}$.

\section{6. おわりに}

以上述べてきたように, 筆者らは, 昆虫の nAChRに対す るネオニコチノイドの選択的アゴニスト作用に対して受容 体の $\alpha$ およびnon- $\alpha$ サブユニットがいずれも梁く関与す ることを，他に先駆けて明らかにしてきた，とくに，non- $\alpha$ サブユニットの役割については，それがネオニコチノイド の最も特徵的な構造であるニト口基との相互作用の場であ る可能性が高いことをはじめて解明したことは，大きな意 義があると思われる。

最近 AChBP の結晶構造をべースにして, nAChRのア ゴニスト結合部位のモデルが提出された ${ }^{17-19)}$.これらのモ デルで，筆者らの研究成果が説明できるのかどうか検討す る必要があろう。亲オコチノイド系殺虫剂の選択毒性の 機構に関する研究とはいえ, 深く掘り下げていくと普遍性 のある問題にたどり着くかもしれない.

\section{引用 文 献}

1) K. Matsuda, S. D. Buckingham, D. Kleier, J. J. Rauh, M. Grauso and D. B. Sattelle : Trends Pharmacol. Sci. 22, 573580 (2001).

2) I. Yamamoto, G. Yabuta, M. Tomizawa, T. Saito, T. Miyamoto and S. Kagabu: J. Pesticide Sci. 20, 33-40 (1995).
3) M. Tomizawa, D. L. Lee and J. E. Casida: J. Agric. Food Chem. 48, 6016-6024 (2000).

4) A. Karlin and M. H. Akabas: Neuron 15, 1231-1244 (1995).

5) J. P. Corringer, N. Le Novere and J. P. Changeux : Annu. Rev. Pharmacol. Toxicol. 40, 431-458 (2000).

6) V. Itier and D. Bertrand : FEBS Lett. 504, 118-125 (2001).

7) A. Karlin : Nature Rev. Neurosci. 3, 102-114 (2002).

8) S. Couturier, D. Bertrand, J.-M. Matter, M.-C. Hernandez, S. Bertrand, N. Millar, S. Valera, T. Barkas and M. Ballivet: Neuron 5, 847-856 (1990).

9) V. Gerzanich, R. Anand and J. Lindstrom: Mol. Pharmacol. 45, 212-220 (1994).

10) A. B. Elgoyhen, D. S. Johnson, J. Boulter, D. E. Vetter and S. Heinemann : Cell 79, 705-715 (1994).

11) D. Bertrand, M. Ballivet, M. Gomez, S. Bertrand, B. Phannavong and E. D. Gundelfinger : Eur. J. Neurosci. 6, 869875 (1994).

12) K. Matsuda, S. D. Buckingham, J. C. Freeman, M. D. Squire, H. A. Baylis and D. B. Sattelle: Br. J. Pharmacol. 128, 518-524 (1998).

13) K. Matsuda, M. Shimomura, Y. Kondo, M. Ihara, K. Hashigami, N. Yoshida, V. Raymond, N. P. Mongan, J. C. Freeman, K. Komai and D. B. Sattelle : Br. J. Pharmacol. 130, 981-986 (2000).

14) A. B. Smit, N. I. Syed, D. Schaap, J. van Minnen, J. Klumperman, K. S. Kits, H. Lodder, R. C. van der Schors, R. van Elk, B. Sorgedrager, K. Brejc, T. K. Sixma and W. P. M. Geraerts : Nature 411, 261-268 (2001).

15) K. Brejc, W. J. van Dijk, R. V. Klaassen, M. Schuurmans, J. van der Oost, A. B. Smit and T. K. Sixma : Nature 411, 269-276 (2001).

16) M. Shimomura, H. Okuda, K. Matsuda, K. Komai, M. Akamatsu and D. B. Sattelle: Br. J. Pharmacol. 137, 162169 (2002).

17) N. Le Novere, T. Grutter and J. P. Changeux : Proc. Natl. Acad. Sci. USA 99, 3210-3215 (2002).

18) C. Fruchart-Gaillard, B. Gilquin, S. Antil-Delbeke, N. Le Novere, T. Tamiya, P. J. Corringer, J. P. Changeux, A. Menez and D. Servent: Proc. Natl. Acad. Sci. USA 99, 3216-3221 (2002).

19) M. Schapira, R. Abagyan and M. Totrov: BMC Struct. Biol. 2, 1 (2002). 